\title{
Korelasi Intensitas Bimbingan Pembimbing Akademik Dengan Indeks Prestasi Mahasiswa di STAI Darul Kamal NW Kembang Kerang
}

\author{
Musabbihin ${ }^{1}$, Muhammad Yamin², Muhammad Sadaruddin 3 , Saupian Sauri ${ }^{4}$ \\ 1ucaks91@gmail.com, ${ }^{2 y y 952618 @ g m a i l . c o m, ~ 3 S h a d a r g h i f a r i 0812 @ g m a i l . c o m, ~}$ \\ ${ }^{4}$ saupiandzikra@gmail.com \\ 1, 2, 3,4 Manajemen Pendidikkan Islam, STAI Darul Kamal, Lombok Timur, Indonesia
}

\begin{abstract}
Abstrak
Pembimbing akademik berperan memberikan nasihat, arahan dan masukan kepada mahasiswa bimbingannya terkait proses perkuliahan. Bimbingan yang diberikan dosen pembimbing diharapkan dapat membantu mahasiswa menyelesaikan proses perkuliahan secara maksimal. Sehingga dapat berdampak positif pada prestasi akademik (Nilai Indek Prestasi) mahasiswa, karena dihipotesiskan bahwa terdapat hubungan positif Antara intensitas bimbingan pembimbing akademik dengan nilai Indeks Prestasi mahasiswa. Penelitian ini bertujuan melihat hubungan antara intensitas bimbingan dosen pembimbing akademik dengan prestasi akademik mahasiswa. penelitian dilakukan dengan memberikan angket kepada mahasiswa STAI darul kamal yang dijadikan sampel. Pemilihan sampel dilakukan dengan teknik random sampling dan didapatkan 30 mahasiswa sebagai sampel penelitian. analisis data hasil penelitian dilakukan dengan uji korelasi. Berdasarkan hasil analisis didapatkan nilai koefisien korelasi atau $\mathrm{r}$ hitung sebesar 0,46827 lebih besar dari nilai $r$ tabel dengan $N=30$ dan taraf signifikansi $5 \%$ yaitu 0,349 sehingga dapat disimpulkan bahwa terdapat hubungan yang signifikan antara intensitas bimbingan pembimbing akademik dengan nilai Indeks Prestasi mahasiswa. Ini berarti semakin intensif bimbingan yang diberikan maka nilai indeks prestasi mahasiswa semakin baik.
\end{abstract}

Kata kunci : Bimbingan, Pembimbing Akademik, Indeks Prestasi

\section{Pendahuluan}

Pendidikan di Indonesia akhir-akhir ini mencanangkan pembelajaran berpusat kepada siswa, dimana guru atau pendidik berperan sebagai fasilitator yang membantu proses belajar peserta didik. Guru diharapkan mampu memfasilitasi minat belajar dan bakat setiap peserta didiknya, dan membantu mereka memaksimalkan potensi yang mereka miliki. Peserta didik diberikan kesempatan untuk belajar sesuai minat dan bakat mereka. Dengan demikian diharapkan tercipta pembelajaran yang 
Jurnal Manajemen dan Budaya STAI Darul Kamal NW Kembang kerang

Volume 1 No 2 Tahun 2021

P-ISSN : 2775-1643

E-ISSN : 2774-6704

https://journal.staidk.ac.id/index.php/manajemenbudaya

menyenangkan. Namun keberagaman minat belajar dan bakat peserta didik membuat guru kewalahan menghadapi mereka.

Guru sebagai fasilitator tidak hanya mengajarkan ilmu pengetahuan, tetapi juga membantu peserta didik mengembangkan skill dan memberikan tauladan untuk membentuk karakter anak. Karena mendidik sejatinya memberikan bimbingan ke arah yang lebih baik melalui nasihat, masukan, arahan dan berbagi pengetahuan. Dengan demikian peserta didik menjadi lebih dari segala sudut, ilmu pengetahuan, skill dan karakter. Sehingga mendidik mendidik akan terasa sangat berat jika dilakukan sendiri.

Tugas mendidik tidak bisa hanya diserahkan kepada guru atau pengajar saja, tetapi juga dibebankan kepada pihak-pihak lain yang terkait seperti orang tua, wali kelas, guru BK dan semua orang yang berinteraksi dengan peserta didik. Pada tingkat perguruan tinggi, selain dosen pengampu mata kuliah sebagai tenaga pengajar, mahasiswa juga didampingi oleh dosen pembimbing akademik, yang membantu mereka menyelesaikan permasalahan permasalahan dalam perkuliahan, baik secara administrasi, birokrasi ataupun yang lainnya.

Pembimbing akademik berperan memberikan nasihat, arahan dan masukan kepada mahasiswa bimbingannya terkait proses perkuliahan. Bimbingan yang diberikan dosen pembimbing diharapkan dapat membantu mahasiswa menyelesaikan proses perkuliahan secara maksimal. Sehingga dapat berdampak positif pada prestasi akademik (Nilai Indek Prestasi) mahasiswa, karena dihipotesiskan bahwa terdapat hubungan positif Antara intensitas bimbingan pembimbing akademik dengan nilai Indeks Prestasi mahasiswa. Penelitian ini bertujuan melihat hubungan antara intensitas bimbingan dosen pembimbing akademik dengan prestasi akademik mahasiswa.

\section{Kajian Teori}

Bimbingan merupakan bantuan yang diberikan kepada invidu dalam proses perkembangan1. Bimbingan dapat juga didefinisikan sebagai proses pemberian

${ }^{1}$ Ahmad Susanto, Bimbingan Dan Konseling Di Sekolah Konsep, Teori, Dan Aplikasinya, Prenadamedia Group Jakarta, 2018. 
Jurnal Manajemen dan Budaya STAI Darul Kamal NW Kembang kerang

Volume 1 No 2 Tahun 2021

P-ISSN : 2775-1643

E-ISSN : 2774-6704

https://journal.staidk.ac.id/index.php/manajemenbudaya

bantuan yang diberikan kepada seseorang atau sekelompok orang serta terus-menerus dan sistematis oleh pembimbing agar individu atau sekelompok individu menjadi pribadi yang mandiri. Pendapat lain mengatakan bimbingan adalah pelayanan yang dilaksanakan oleh tenaga ahli dengan latihan-latihan khusus, dan untuk melaksanakan pelayanan bimbingan diperlukan minat pribadi khusus pula².

Bimbingan sangat diperlukan karena setiap mahasiswa berasal dari latar belakang yang sangat bervariasi, baik dari jenis kelamin, asal sekolah, kehidupan keluarga, status sosial dan tingkatan ekonomi orang tua. Latar belakang itu mempengaruhi cara belajar mahasiswa dan mempengaruhi prestasi belajar yang dicapai.

Pelaksanaan bimbingan dapat dilakukan oleh banyak pihak. Salah satu pihak yang ditunjuk secara resmi adalah penasihat akademik. Penasihat akademik memiliki tugas memberikan nasihat dan petunjuk kepada mahasiswa bimbingannya guna membantu kelancaran studinya. Pemberian nasihat dan petunjuk dalam hal ini menyangkut berbagai hal yang berhubungan dengan kelancaran studinya seperti pemberian bimbingan minimal dua kali setiap semester, pemberian bantuan kepada mahasiswa dalam mengatasi kesulitan-kesulitan yang dihadapi studinya, serta memberi teguran kepada mahasiswa bimbingannya baik lisan maupun tulisan apabila prestasi akademik mahasiswa yang bersangkutan menurun.

Dalam dunia kampus mahasiswa dituntut untuk berkompetisi dalam memperoleh prestasi akademik, dimana tolak ukurnya adalah indeks prestasi. Prestasi akademik adalah hasil pelajaran yang diperoleh dari kegiatan belajar di sekolah atau perguruan tinggi yang bersifat kognitif dan biasanya ditentukan melalui pengukuran dan penilaian \{Hadi: 2012\}. Selain itu prestasi merupakan kumpulan dokumen yang berisi hasil penilaian prestasi belajar, penghargaan, karya peserta didik dalam bidang tertentu yang bersifat reflektif-integratif dalam kurun waktu tertentu.

Keberasilan bimbingan pembimbing akademik mahasiswa, ditandai dengan prestasi akademik yang dicapai, ditunjukan melalui indeks prestasi (IP) maupun

\footnotetext{
${ }^{2}$ Abu bakar M luddin, Dasar-Dasar Konseling Tinjauan Dan Teori Praktik, Bandung Perdana Mulya Perdana, 2010.
} 
Jurnal Manajemen dan Budaya STAI Darul Kamal NW Kembang kerang

Volume 1 No 2 Tahun 2021

P-ISSN : 2775-1643

E-ISSN : 2774-6704

https://journal.staidk.ac.id/index.php/manajemenbudaya

indeks prestasi komulatif (IPK). Indeks prestasi komulatif merupakan angkan yang menunjukan prestasi atau kemajuan belajar mahasiswa secara komulatif mulai dari semester pertama sampai dengan semester paling akhir yang telah ditempuh.

1. Ruang Lingkup Bimbingan Akademik Ruang lingkup bimbingan akademik meliputi:

a. Tugas dan hak Dosen Pembimbing Akademik dan Mahasiswa

b. Tata cara pembimbingan akademik

C. Standar waktu pembimbingan setiap kegiatan

2. Tujuan Bimbingan Akademik

Bimbingan yang dilakukan memiliki tujuan tercapainya penyesuaian diri, perkembangan optimal dan kemandirian dari peserta $\operatorname{didik}^{3}$. Melalui pembimbingan akademik yang intensif diharapkan mahasiswa dapat menyelesaikan studi tepat pada waktunya dengan hasil yang memuaskan ${ }^{4}$

3. Tugas Pembimbing Akademik Tugas pembimbing akademik meliputi:

a. Memberikan nasehat dan petunjuk kepada mahasiswa bimbingannya guna membantu kelancaran studinya.

b. Memberikan pengarahan kepada mahasiswa dalam memilih mata kuliah dan membantu dalam memilih mata kuliah dan membantu dalam menetapkan jumlah sks yang diprogramkan setiap awal semester sesuai ketentuan yang berlaku.

c. Memberikan pertimbangan kepada Ketua Jurusan/Dekan tentang hal-hal yang berkenaan dengan mahasiswa bimbingannya.

d. Mengikuti dengan seksama perkembangan studi mahasiswa yang dibimbingnya dan membantu mahasiswa mengatasi kesulitan-kesulitan yang dihadapi berkaitan dengan studi.

e. Memeriksa Buku Kemajuan Mahasiswa (BKM) dan memberi paraf sebagai bukti pemantauan minimal 2 kali setiap semester.

${ }^{3}$ Pupu Saeful Rahmat, Psikologi Pendidikan (Bumi Aksara, 2021).

${ }^{4}$ LPM STAI Darul Kamal, Standar Operasional Prosedur Bimbingan Akademik (Indonesia, 2018). 
Jurnal Manajemen dan Budaya STAI Darul Kamal NW Kembang kerang

Volume 1 No 2 Tahun 2021

P-ISSN : 2775-1643

E-ISSN : 2774-6704

https://journal.staidk.ac.id/index.php/manajemenbudaya

f. Memberi teguran kepada mahasiswa bimbingannya, baik lisan maupun tulisan apabila prestasi akademik mahasiswa yang bersangkutan menurun.

g. Memberikan pertimbangan kepada mahasiswa bimbingannya yang mengajukan cuti akademik atau yang terancam DO.

h. Menyampaikan laporan secara tertulis atas pelaksanaan tugasnya kepada Ketua Jurusan/Dekan setiap akhir semester sesuai program kerja.

4. Hak Pembimbing Akademik Adapun hak pembimbing akademik:

a. Memanggil dan memberi peringatan kepada mahasiswa bimbingannya yangmelakukan pelanggaran kode etik mahasiswa.

b. Meneruskan permasalahan mahasiswa yang bukan kewenangan atau di luarkemampuan dosen PA kepada Ketua Jurusan untuk dapat diselesaikan.

c. Merekomendasikan mahasiswa bimbingannya yang berprestasi dan layak mendapatkan beasiswa ${ }^{5}$.

5. Tugas Mahasiswa

Adapun tugas mahasiswa berkaitan dengan bimbingan akademik antara lain:

a. Setiap mahasiswa wajib mengikuti tata tertib yang berlaku di STAI Darul Kamal NW Kembang Kerang, yang telah tertuang di dalam buku pedoman edukasi.

b. Setiap mahasiswa wajib datang pada saat bimbingan dan tidak diwakilkan, kecuali jika berhalangan karena sakit atau ada izin dari orang tua/wali.

c. Setiap mahasiswa bimbingan harus mempunyai buku bimbingan, dan bukutersebut harus dibawa setiap bimbingan akademik ${ }^{6}$.

6. Hak Mahasiswa

Adapun hak mahasiswa berkaitan dengan bimbingan akademik antara lain

a. Setiap mahasiswa berhak mendapatkan bimbingan dari dosen PA minimal

\footnotetext{
${ }^{5}$ LPM STAI Darul Kamal, Standar Operasional Prosedur Bimbingan Akademik.

${ }^{6}$ LPM STAI Darul Kamal, Pedoman Layanan Kemahasiswaan (Indonesia, 2018).
} 
Jurnal Manajemen dan Budaya STAI Darul Kamal NW Kembang kerang

Volume 1 No 2 Tahun 2021

P-ISSN : 2775-1643

E-ISSN : 2774-6704

https://journal.staidk.ac.id/index.php/manajemenbudaya

dua kali persemester

b. Setiap mahasiswa yang berprestasi dan belum pernah mendapat beasiswa berhak direkomendasikan untuk mengikuti seleksi beasiswa yang ditawarkan oleh perguruan tinggi ${ }^{7}$.

7. Penunjukan Dosen Pembimbing Akademik

Adapun penunjukan Dosen Pembimbing Akademik yaitu:

a. Dekan mengangkat dosen PA atas usulan ketua jurusan yang dituangkan dalam bentuk SK Dekan tiap semester untuk membimbing 1 kelompok mahasiswa.

b. Dosen PA yang tidak berada di kampus untuk sementara waktu, maka tugas sebagai PA dapat digantikan oleh Ketua Jurusan setelah ada pemberitahuan atau permintaan untuk diwakilkan dari pembimbing akademik.

c. Dosen PA yang meninggalkan tugas selama 6 bulan atau lebih, tugasnya sebagai PA digantikan dosen lain dengan SK Dekan atas usulan ketua program studi ${ }^{8}$.

8. Tata Cara Bimbingan Akademik

Adapun tata cara pembimbingan akademik sebagai berikut:

a. Dosen PA menetapkan dan mengumumkan jadwal bimbingan setiap awal semester.

b. Dosen PA mengevaluasi hasil kuliah semester sebelumnya, serta memberikan bimbingan akademik untuk semester selanjutnya.

c. Mahasiswa mengisi KRS sesuai jadwal yang telah ditentukan kemudian melaporkan kepada PA.

d. Dosen PA memvalidasi KRS dalam waktu 2 minggu dimulai sejak berakhirnyapengisian KRS oleh mahasiswa.

e. Mahasiswa mencetak KRS untuk ditandatangani oleh dosen PA.

f. Mahasiswa berkonsultasi dengan dosen PA minimal 2 kali setiap semester,

${ }^{7}$ LPM STAI Darul Kamal, Pedoman Layanan Kemahasiswaan.

8 LPM STAI Darul Kamal, Standar Operasional Prosedur Bimbingan Akademik. 
Jurnal Manajemen dan Budaya STAI Darul Kamal NW Kembang kerang

Volume 1 No 2 Tahun 2021

P-ISSN : 2775-1643

E-ISSN : 2774-6704

https://journal.staidk.ac.id/index.php/manajemenbudaya

baikakademik maupun non-akademik ${ }^{9}$.

Dengan melihat pembahasan mengenai bimbingan akademik, maka penulis dapat memberikan gambaran bahwa bimbingan akademik pada umumnya meliputi semua kegiatan yang dilaksanakan Penasehat Akademik sesuai ketentuan-ketentuan yang berlaku serta tujuan yang ingin dicapai yaitu membantu mahasiswa untuk menyelesaikan studi akademiknya.

\section{Prestasi Belajar}

Di dalam kamus besar bahasa Indonesia, dikemukakan bahwa prestasi adalah hasil yang telah dicapai, dilakukan dan dikerjakan. Sedangkan belajar adalah berusaha atau berlatih untuk mendapat ilmu/pengetahuan.

Menurut pengertian secara psikologis, belajar merupakan suatu proses perubahan yaitu perubahan tingkah laku sebagai hasil dari interaksi dengan lingkungannya dalam memenuhi kebutuhan hidupnya. Perubahan-perubahan tersebut akan nyata dalam seluruh aspek tingkah laku.

Dalam pengertian luas, belajar dapat diartikan sebagai kegiatan psiko- fisik menuju ke perkembangan pribadi seutuhnya ${ }^{10}$. Kemudian dalam arti sempit, belajar dimaksudkan sebagai usaha penguasaan materi ilmu pengetahuan yang merupakan sebagian kegiatan menuju terbentuknya kepribadian seutuhnya.

Skinner berpandangan bahwa belajar adalah suatu perilaku. Pada saat orang belajar, maka responnya menjadi lebih baik. Sebaliknya, bila ia tidak belajar maka responnya menurun.

Sardiman A.M. mengemukakan bahwa belajar merupakan perubahan tingkah laku atau penampilan, dengan serangkaian kegiatan misalnya dengan membaca, mengamati, mendengarkan, meniru dan lain sebagainya ${ }^{11}$.

Dimyati dan Mudjiono mengemukakan bahwa belajar merupakan proses internal yang kompleks, yang terlibat dalam proses internal tersebut adalah seluruh

\footnotetext{
${ }^{9}$ LPM STAI Darul Kamal, Standar Operasional Prosedur Bimbingan Akademik.

10 Aep Rohendi, 'Pembelajaran Bola Voli Berbasis Permainan', Buku Bahan Ajar, 2017.

11 Sardiman A.M, Interaksi Dan Motivasi Belajar Mengajar, Jurnal Medtek, 2007.
} 
Jurnal Manajemen dan Budaya STAI Darul Kamal NW Kembang kerang

Volume 1 No 2 Tahun 2021

P-ISSN : 2775-1643

E-ISSN : 2774-6704

https://journal.staidk.ac.id/index.php/manajemenbudaya

mental yang meliputi ranah-ranah kognitif, afektif, dan psikomotorik ${ }^{12}$.

Berdasarkan pengertian di atas, maka dapat diartikan bahwa prestasi belajar adalah hasil yang telah dicapai atau diperoleh oleh peserta didik yang berupa pengetahuan, keterampilan dan sikap berkat pengalaman dan latihan yang telah dilalui oleh individu. Sehingga prestasi belajar mencakup aspek kognitif, afektif dan psikomotorik.

\section{Metode Penelitian}

Jenis penelitian ini termasuk jenis penelitian lapangan \{field research\} dengan menggunakan pendekatan kuantitatif \{Suheri: 2017\}. Pengukuran kuantitatif ini dilakukan untuk mengetauhi korelasi intensitas bimbingan pembimbing akademik dengan indeks prestasi mahasiswa di STAI Darul Kamal NW Kembang Kerang.

Tehnik pengambilan sampel menggunakan random sampling. Populasi penelitian ini adalah mahasiswa dan mahasiswi STAI Darul Kamal NW Kembang Kerang dengan mengambil sampel sebanyak 30 orang mahasiswa/ mahasiswi dari semua Prodi di STAI. Tehnik pengumpulan data menggunakan angket untuk mengetauhi hasil bimbing pembimbing akademik dengan indeks prestasi mahasiswa, analisis yang digunakan korelasi intensintas.

\section{Pembahasan}

Data hasil penelitian menunjukan nilai IP terendah mahasiswa yang dijadikan sampel penelitian adalah 3.25 dan tertinggi 3.70 dengan rentang 0.45 dan diperoleh rerata sebesar 3.457. Sedangkan nilai tengah atau median sebesar 3.45 dan nilai modus sebesar 3.45. nilai rerata dan nilai modus sangat dekat sehingga dapat dikatakan bahwa sample berdistribusi normal. Dengan demikan data hasil penelitian dapat digunakan untuk analisis selanjutnya untuk menguji hipotesis.

12 Mudjiono Dimyati, Belajar Dan Pembelajaran. Cetakan, Rineka Cipta:Jakarta, 2013. 
Pengujian hipotesis penelitian dimaksudkan untuk mengetahui apakah hipotesis yang diajukan ditolak atau diterima pada taraf signifikansi tertentu ${ }^{13}$. Hipotesis nol $\left(\mathrm{H}_{0}\right)$ pada penelitian ini adalah "terdapat hubungan yang signifikan antara intensitas bimbingan pembimbing akademik dengan indeks prestasi mahasiswa", dan hipotesis tandingannya adalah "tidak terdapat hubungan yang signifikan antara intensitas bimbingan pembimbing akademik dengan indeks prestasi mahasiswa". Sehingga uji hipotesis dilakukan dengan uji korelasi. Tabel 1 menunjukan hasil uji korelasi intensitas bimbingan pembimbing akademik dengan indeks prestasi mahasiswa menggunakan Ms. Excel.

Tabel 1. Hasil Uji Korelasi

\begin{tabular}{lrr}
\hline & Indeks Preestasi & Intnsitas Bimbngan \\
\hline Indeks Preestasi & 1 & \\
Intnsitas Bimbngan & 0.416827221 & 1 \\
\hline
\end{tabular}

Tabel 1 menunjukan nilai koefisien korelasi atau $r$ hitung sebesar 0,46827 lebih besar dari nilai $\mathrm{r}$ tabel dengan $\mathrm{N}=30$ dan taraf signifikansi 5\% yaitu 0,349 maka $\mathrm{H}_{0}$ diterima. Sehingga dapat disimpulkan bahwa terdapat hubungan yang signifikan antara intensitas bimbingan pembimbing akademik dengan nilai Indeks Prestasi mahasiswa. Ini berarti semakin intensif bimbingan yang diberikan maka nilai indeks prestasi mahasiswa semakin baik. Meskipun hubungan tidak terlalu kuat, bimbingan yang diberikan dosen terbukti berdamapak pada nilai indeks prestasi mahasiswa.

Intensitas bimbingan yang diberikan dosen pembimbing pada penelitian ini diukur melalui 4 indikator yaitu: 1) Intensitas pertemuan, 2) Memberikan arahan dan masukan yang solutif, 3) Mengajarkan strategi belajar efisien dan efektif, 4) Membantu dan atau memudahkan proses administrasi, dan 5)

\footnotetext{
13 Indra Sakti, 'Korelasi Pengetahuan Alat Praktikum Fisika Dengan Kemampuan Psikomotorik Siswa Di Sma Negeri Kota Bengkulu', Jurnal Exacta, IX.1 (2011), 67-76.
} 
Memberikan motivasi dan semangat. Dari 4 indikator tersebut yang berhubungan secara lansung dengan indeks prestasi mahasiswa adalah indikator ke-3 yaitu Mengajarkan strategi belajar efisien dan efektif. Sehingga ini yang paling memungkinkan memberikan dampak pada indeks prestasi mahasiswa.

\section{Kesimpulan}

Korelasi antara intensitas bimbingan pembimbing akademik dengan indeks prestasi mahasiswa terbukti ada pada taraf signifikansi 5\% dimana nilai $r$ hitung $(0,46827)$ lebih besar dari nilai $r$ tabel $(0,349)$, meskipun korelasinya tidak begitu kuat karena rentangnya cukup kecil $(0,119)$. . Sehingga dapat disimpulkan bahwa terdapat hubungan yang signifikan antara intensitas bimbingan pembimbing akademik dengan nilai Indeks Prestasi mahasiswa. Ini berarti semakin intensif bimbingan yang diberikan maka nilai indeks prestasi mahasiswa semakin baik

\section{Daftar Referensi}

A.M, Sardiman, Interaksi Dan Motivasi Belajar Mengajar, Jurnal Medtek, 2007

Aep Rohendi, 'Pembelajaran Bola Voli Berbasis Permainan', Buku Bahan Ajar, 2017

Dimyati, Mudjiono, Belajar Dan Pembelajaran. Cetakan, Rineka Cipta:Jakarta, 2013

LPM STAI Darul Kamal, Pedoman Layanan Kemahasiswaan (Indonesia, 2018)

- - - , Standar Operasional Prosedur Bimbingan Akademik (Indonesia, 2018)

M luddin, Abu bakar, Dasar-Dasar Konseling Tinjauan Dan Teori Praktik, Bandung Perdana Mulya Perdana, 2010

Rahmat, Pupu Saeful, Psikologi Pendidikan (Bumi Aksara, 2021)

Sakti, Indra, 'KORELASI PENGETAHUAN ALAT PRAKTIKUM FISIKA DENGAN KEMAMPUAN PSIKOMOTORIK SISWA DI SMA NEGERI q KOTA BENGKULU', Jurnal Exacta, IX (2011), 67-76

Susanto, Ahmad, Bimbingan Dan Konseling Di Sekolah Konsep, Teori, Dan Aplikasinya, Prenadamedia Group Jakarta, 2018 